\title{
Trichostatin A improved epigenetic modifications of transgenic cells but did not improve subsequent cloned embryo development
}

\author{
Xia $\mathrm{Wu}^{1}$, Hai-quan $\mathrm{Yu}^{1}$, Guang-Peng $\mathrm{Li}^{1}$, Shorgan Bou ${ }^{1}$ \\ ${ }^{I}$ The Key Laboratory of Mammalian Reproductive Biology and Biotechnology of the Ministry of Education, Inner Mongolia \\ University, Hohhot 010021, China
}

Despite cloning animals from adult cells were produced in various species, cloning remains an extremely inefficient process. Reprogramming impairment of DNA methylation may be partly responsible for the low efficiency in somatic cell nuclear transfer. In this study, bovine fibroblast cells were transfected with enhancer green fluorescence protein (eGFP), and then treated with a histone-deacetylase inhibitor, trichostatin A (TSA). The results showed that the effect of TSA on transgenic cells was in a dose-dependent manner. When the TSA concentration was over $5 \mathrm{ng} / \mathrm{mL}$ cell proliferation was significantly inhibited. The majority of the cells died when TSA reached $100 \mathrm{ng} / \mathrm{mL}(P<0.01)$. Number of cells in S phase was significantly decreased in the 5 to $50 \mathrm{ng} / \mathrm{mL}$ TSA-treated groups, while the majority of the cells were at G0/G1 phases. Expression of eGFP were approximately two-fold higher in $25 \mathrm{ng} / \mathrm{mL}(31.7 \%)$ and 50 $\mathrm{ng} / \mathrm{mL}(32.2 \%)$ TSA groups when compared to the control (15.0\%). Reduced DNA methylation and improved histone acetylation were observed when the cells were treated with 10 to $50 \mathrm{ng} / \mathrm{mL}$ TSA. Transfer of the TSA-treated cells to enucleated recipient oocytes resulted in similar cleavage rates among the experimental groups and the control. Cells treated with $50 \mathrm{ng} / \mathrm{mL}$ TSA resulted in significantly lower blastocyst development $(9.9 \%)$ than the other experimental and the control groups (around $20 \%$ ). Analysis of the putative blastocysts showed that $86.1 \%$ of the embryos derived from TSA-treated cells were eGFP positive, which was higher than that from untreated cells $(\mathbf{7 3 . 4 \% )}$ ). In conclusion, transgenic cells were more sensitive to TSA treatment than non-transgenic cells. Treatment of transgenic cells with TSA decreased the genome DNA methylation level, and eGFP gene expression was activated. Donor cells with reduced DNA methylation did not improve subsequent cloned embryo development. However, transfer gene expression was improved in cloned embryos.

Keywords: Trichostatin A, eGFP, epigenetic modifications, nuclear transfer, bovine

Cell Research (2008) 18:s144. doi: 10.1038/cr.2008.234; published online 4 August 2008

Correspondence: Haiquan Yu

E-mail: haiquan_yu@yahoo.com 